\title{
Tratamento de úlcera indolente em equino
}

Heitor Dourado Simões ${ }^{[a] ", ~ R o b e r t o ~ P i m e n t a ~ d e ~ P a ́ d u a ~ F o z ~ F i l h o ~}{ }^{[b]}$, felipe Garcia Tosta ${ }^{[c]}$, Gustavo Pereira Rocha ${ }^{[a]}$, Fabio Feitosa ${ }^{[a]}$, Marcos Vinicios Feitosa ${ }^{[a]}$

\author{
${ }^{[a]}$ Médico veterinário, São Paulo, SP, Brasil \\ [b] Universidade Anhembi Morumbi (UAM), Jundiaí, SP, Brasil \\ [c] Faculdade de Jaguariúna (FAJ), Jaguariúna, SP, Brasil
}

*Autor correspondente

e-mail: heitor_dourado_simoes@hotmail.com

\section{Resumo}

As sinusites correspondem à inflamação dos seios paranasais, geralmente causadas por infecções bacterianas, associadas ou não a problemas dentários ou etiologias secundárias como o trauma. Algumas fraturas faciais cicatrizam espontaneamente, porém a falha no seu tratamento pode gerar sinusites, sequestro ósseo, deformidade facial, fístulas e adelgaçamento do septo nasal ou necrose. Fraturas faciais envolvendo os seios paranasais e a cavidade nasal são comuns como resultado direto de traumas, e a cirurgia reconstrutiva deve ser realizada o mais previamente possível, possibilitando melhores resultados. A trepanação permite acesso limitado aos seios paranasais. 0 procedimento pode ser realizado com o animal em estação e devidamente sedado, permitindo exames diagnósticos ou procedimentos terapêuticos, tais como endoscopia, aspirações, lavagens, biópsias, repulsão ortodental e número reduzido de procedimentos cirúrgicos. Duas fêmeas Meio Sangue PSI com idade entre 4 e 6 anos, utilizadas na prática de polo, apresentaram sinusite com secreção purulenta por uma narina. No primeiro caso, a sinusite foi secundária à infecção do trato respiratório superior, e no segundo caso foi secundária a trauma direto no osso frontal com fratura do mesmo. Ambas foram tratadas na propriedade com antibioticoterapia. Devido à persistência da secreção nasal mesmo após o tratamento com antibióticos, optou-se pela trepanação para lavagem do seio paranasal frontal, feita nas propriedades com o animal em estação, sob sedação com acepromazina 1\% e xilazina 10\%, e infiltração local de lidocaína a $2 \%$. Procedeu-se na incisão da pele até o periósteo do osso frontal. Foi utilizada uma furadeira para acesso ao seio paranasal frontal. Nas lavagens, utilizou-se $10 \mathrm{ml}$ de iodopovidona diluídos em um litro de solução fisiológica. No caso da fratura causada por um coice, o tecido se encontrava espessado e aderido ao periósteo, dificultando a divulsão. Foram removidos dois pequenos fragmentos. No animal que 
apresentou infecção prévia do trato respiratório, foi instalada uma sonda do tipo peltzer, que foi utilizada para lavagem diária do seio frontal por 20 dias, associada ao uso de metronidazol 4g/dia por sete dias e sulfa + trimetropin oral por 20 dias. Consideramos que a técnica da trepanação com utilização de furadeira na propriedade permitiu o tratamento da afecção. Outra vantagem foi o fato de se evitar o estresse do transporte e troca de ambiente. Como desvantagem, consideramos as dificuldades dos procedimentos realizados com o animal em estação e apenas sedado, além das limitações de arsenal terapêutico e de instalações que podemos ter na propriedade, quando comparados aos do hospital veterinário.

Palavras-chave: Trepanação. Cirurgias em estação. Sinusite. 